\title{
SENGKETA BERKEPANJANGAN DALAM PANDANGAN ANTROPOLOGI HUKUM
}

\author{
Nama : DERZANSA \\ Email : derzansa74@gmail.com \\ No.Bp : 2010003600381 \\ FAKULTAS HUKUM UNIVERSITAS EKASAKTI PADANG
}

\section{A. PENDAHULUAN}

Pemahaman unifikasi hukum sudah dijalankan cukup lama di NKRI. Berbagai peraturan perundangan kemudian dibuat sesuai dengan konsepsi di atas. Tujuan unifikasi peraturan perundangan tersebut adalah agar terjadi pelaksanaan hukum yang terkoordinasi, lebih tertib dan kinerjanya diharapkan meningkat (Sunaryati Hartono, 1993; 9). Lalu, pertanyaannya apakah kenyataannya demikian? Perdebatan untuk jawaban itupun setidaknya bisa terpilah dua, yang satu berkenaan dengan susunan yuridis normatifnya, satunya lagi mengenai efektivitas peraturannya di lapangan. Namun, rata-rata di antara kita akan menyatakan bahwa kondisi dan kinerja hasil unifikasi hukum belum juga mengalami perbaikan signifikan. Pada saat yang sama, bahkan telah berlangsung jauh lebih lama terdapat pelbagai sistem hukum dari masyarakat dan kebudayaan-kebudayaan lain ( the other cultures ) selain state law ( hukum negara).

Masyarakatnya mempertahankan sistem-sistem hukum tersebut secara dinamis sesuai dengan laju kebudayaannya. Sebagian pihak menganggap the other laws bagian dari masa lalu, namun sebagian lagi menyatakan bahwa mereka tetap eksis hingga kini. Dan, sebagian lainnya menyatakan ada, namun semakin terkikis ( Parsudi Suparlan, 1980 ; 20-23 ). Karena konsep 'unifikasi hukum' tetap didahulukan, maka keberadaan the other laws (hukumhukum masyarakat lokal) menjadi terkendala. Kendalanya adalah: a) dari sisi masyarakat pemilik hukum lokal, mereka semakin tidak leluasa dalam mengimplementasikan hukumnya,b) dari sisi state, hukum-hukum lain ditanggapi sebagai ganjalan yang dapat menghambat proses pembangunan (semesta) (Roger M. Keesing, 1992; 294). Benturan antara state law versus the other laws kemudian terjadi, dan dinamikanya terkadang tinggi, dan rendah. Konsep inilah yang dalam kajian antropologi hukum dikenal sebagai konsep terjadinya benturan antara legal centralism (pemusatan hukum) dengan legal pluralism (kemajemukan hukum). 


\section{B. PEMBAHASAN}

Sengketa merupakan suatu masalah sosial yang bersifat universal, Karena itu, konflik tidak perlu dilihat sebagai gejala patologis yang bersumber dari tingkah laku abnormal, atau indikasi dari suatu kekacauan dalam dinamika kehidupan masyarakat, karena setiap komunitas masyarakat mempunyai kapasitas untuk menciptakan normanorma dan mekanisme-mekanisme tersendiri untuk menyelesaikan sengketa yang muncul dalam pergaulan sosial warga masyarakat (Nader, 1968; Coser, 1968; Roberts, 1979, Moore, 1978).

Dari perspektif antropologi hukum, fenomena sengketa mempunyai makna ganda, yaitu

Di satu sisi sengketa mempunyai makna menimbulkan perpecahan atau disintegrasi suatu kehidupan sosial, melemahkan kohesi sosial, atau menimbulkan kerusakan suatu sistem hubungan sosial dalam masyarakat. Tetapi, di sisi lain sengketa juga memiliki makna positif dalam mempertahankan integrasi sosial, memperkokoh ikatan sosial, dan memberi kontribusi untuk mengembalikan keseimbangan hubungan sosial antar individu atau kelompok dalam masyarakat. Yang disebutkan terakhir akan dapat terwujud apabila pihak-pihak yang bersengketa secara bersama-sama dapat mengelola, mengendalikan, dan menyelesaikan sengketa yang dihadapi secara dewasa, bijak, dan damai, dengan atau tanpa mengundang kehadiran pihak ketiga (Gluckman, 1956).

Dengan kata lain, dari perspektif antropologi hukum dikatakan sengketa tidak selalu bermakna negatif dalam kehidupan masyarakat, karena sengketa juga mempunyai makna positif yang dapat memperkokoh integrasi dan kohesi hubungan sosial dalam masyarakat, atau mengembalikan keseimbangan hubungan dan sendi-sendi kehidupan sosial. Jadi, sesungguhnya sengketa yang terjadi dalam masyarakat mengandung arti yang konstruktif dan bersifat integratif, karena sengketa juga mempunyai kekuatan tersendiri untuk membentuk, mengembangkan, menertibkan ulang suatu relasi sosial, interaksi, atau tatanan kehidupan yang sudah ada dalam masyarakat (Roberts, 1978).

Secara umum dikatakan bahwa terjadinya sengketa dalam masyarakat bersumber dari persoalan-persoalan seperti berikut: 
1. Penguasaan, pemanfaatan dan distribusi sumber daya alam yang menjadi pendukung kehidupan manusia (natural resource control and distribution)

2. Ekspansi batas wilayah kehidupan suatu kelompok

3. Kegiatan ekonomi masyarakat (economic activities)

4. Kepadatan penduduk

5. Hukum dan kebijakan pemerintah

6. Politik

7. Kemiskinan

Dari perspektif antropologi hukum, sengketa yang terjadi dalam masyarakat paling tidak dapat dikategorisasi menjadi 3 (tiga) macam, yaitu

$\checkmark$ Konflik kepentingan (conflict of interests)

$\checkmark$ Konflik nilai-nilai (conflict of values)

$\checkmark$ Konflik normanorma (conflict of norms).

Dalam hubungan ini, Nader dan Todd (1978) menyatakan bahwa pada dasarnya sengketa yang terjadi dalam masyarakat melalui tahapan-tahapan (stages of conflict) seperti berikut :

$\checkmark$ Pada tahap pertama, sengketa berawal dari munculnya keluhankeluhan (grievance) dari salah satu pihak terhadap pihak yang lain (individu atau kelompok) karena pihak yang mengeluh merasa hakhaknya dilanggar, diperlakukan secara tidak wajar, kasar, dipersilahkan, diinjak harga dirinya, dirusak nama baiknya, dilukai hatinya, dll. Kondisi awal seperti ini disebut sebagai tahapan prakonflik (pro-conflict stage) yang cenderung mengarah kepada konfrontasi yang bersifat monadik (monadic).

$\checkmark$ Pada tahap kedua, apabila kemudian pihak yang lain menunjukkan reaksi negatif berupa sikap yang bermusuhan atas munculnya keluhan-keluhan dari pihak yang pertama, maka kondisi ini meningkat eskalasinya menjadi situasi konflik (conflict stage) sehingga konfrontasi antar pihak-pihak berlangsung secara diadik (diadic).

Pada tahap ketiga, apabila kemudian konflik antar pihak-pihak tersebut ditunjukkan dan bawa ke arena publik (masyarakat), dan kemudian diproses menjadi kasus perselisihan dalam institusi penyelesaian sengketa tertentu dengan melibatkan pihak ketiga, maka situasinya telah meningkat menjadi 
sengketa (dispute stage), dan sifat konfrontasi antar pihak-pihak yang berselisih menjadi triadik (triadic).

\section{Penyelesaian dalam sengketa Antropolgi Hukum.}

Setiap bentuk masyarakat di mana pun dan kapan pun pada dasarnya mempunyai kemampuan untuk menciptakan norma-norma dan mekanisme-mekanisme serta membangun institusi-institusi tertentu untuk menyelesaikan setiap sengketa yang muncul dalam masyarakat (Moore, 1978).

Masyarakat memberi makna sengketa sebagai bagian dari dinamika kehidupan sosial, dan makna sengketa yang diberikan masyarakat juga sangat tergantung pada nilai-nilai, kepercayaan, dan norma-norma yang dianut, serta bentuk-bentuk institusi sosial yang dibangun untuk menyelesaikan sengketa (Roberts, 1978). Sistem nilai, norma, politik, ekonomi, dan keyakinan sangat mempengaruhi pilihan bentuk institusi dan model-model penyelesaian sengketa dalam masyarakat.

Institusi penyelesaian sengketa yang dikenal dalam masyarakat paling tidak ada 2 (dua) macam, yaitu:

$\checkmark$ Institusi penyelesaian sengketa yang bersifat tradisional, yang bersumber dari sistem politik dan hukum rakyat dan berlangsung secara tradisional (folk institutions)

$\checkmark$ Institusi penyelesaian sengketa yang dibangun dan sistem politik dan hukum negara (state institutions).

Dalam kondisi masyarakat yang masih sederhana dan subsisten, di mana relasi antar individu, hubungan kekerabatan dan kelompok masih kuat, maka pilihan institusi untuk menyelesaikan sengketa diarahkan kepada institusi-institusi penyelesaian sengketa yang bersifat kerakyatan (folk institutions), karena institusi penyelesaian sengketa yang bersifat tradisional bermakna sebagai institusi penjaga keteraturan sosial (social order) dan dimaksudkan untuk pengembalian keseimbangan magis dalam masyarakat. Karena itu, makna penyelesaian sengketa melalui institusi tradisional dengan mengacu pada hukum rakyat (folk law) lebih ditujukan untuk mengembalikan hubungan sosial yang terganggu dan lebih dari itu mengembalikan keseimbangan magis dalam masyarakat (win-win solution). Sedangkan, sengketa yang terjadi dalam masyarakat yang kompleks dan modern, di mana relasi sosial lebih bersifat individualistik, berorientasi pada perekonomian pasar, cenderung diselesaikan melalui institusi penyelesaian sengketa yang formal dengan mengacu pada hukum negara (state institution) yang bercirikan legalistik. Institusi peyelesaian sengketa yang mengacu pada hukum negara 
dikenal sebagai pengadilan (courtinstitution), yang digerakkan oleh hakim-hakim pengadilan (judges), dengan menerima, memeriksa dan memutuskan suatu sengketa untuk menyatakan pihak yang satu menang dan pihak yang lain kalah dalam sengketa tersebut (win-lose solution) (F. von BendaBeckmann, 1986).

Sedangkan, model-model penyelesaian sengketa yang dikenal dalam masyarakat sederhana maupun kompleks (modern) pada pokoknya adalah:

\section{Negosiasi,}

melalui proses kompromi antara pihak-pihak yang bersengketa tanpa mengundang kehadiran pihak ketiga untuk menyelesaikan sengketa yang terjadi di antara mereka.

\section{Mediasi}

melalui kesepakatan antara pihak-pihak untuk melibatkan pihak ketiga (mediator) dalam penyelesaian sengketa, walau hanya berfungsi sebatas perantara (go-between) yang bersifat pasif, karena inisiatif untuk mengambil keputusan sebagai wujud penyelesaian sengketanya tetap didasarkan pada kesepakatan pihak-pihak yang bersengketa.

\section{Arbitrasi}

melalui kesepakatan untuk melibatkan pihak ketiga yang disebut arbitrator sebagai wasit yang memberi keputusan dan keputusan tersebut harus ditaati dan dilaksanakan oleh pihak-pihak yang bersengketa.

\section{Ajudikasi}

sebagai model penyelesaian sengketa melalui institusi pengadilan yang keputusannya mengikat pihak-pihak yang bersengketa (Roberts, 1978).

Namun demikian, selain model-model penyelesaian sengketa seperti di atas, dalam masyarakat dikenal juga model-model penyelesaian sengketa seperti :

\section{Tindakan kekerasan (coersion)}

sebagai aksi yang bersifat unilateraldengan mengandalkan kekuatan fisik dan kekerasan, seperti melakukan tindakan hukum sendiri (self-hell) atau dalam bentuk perang antar suku (warfare).

\section{Tindakan membiarkan saja (lumping it)}

yang dilakukan oleh salah satu pihak dengan tidak menanggapi keluhan, gugatan, tuntutan pihak yang lain, atau mengabaikan sengketa yang terjadi dengan pihak yang lain.

\section{Tindakan penghindaran (avoidance)}

yang dilakukan salah satu pihak dengan menghindari sengketa dengan pihak lain, karena sejak awal sengketa yang bersangkutan merasa secara sosial, 
ekonomi, politik, dan psikologis merasa sudah tidak berdaya untuk menghadapi pihak yang lain.

Dengan demikian, tindakan menghindari sengketa dipandang paling aman dan menguntungkan tidak saja bagi diri sendiri, tetapi juga bagi keluarga dan kerabat, dalam rangka menjaga hubungan sosial yang bersifat jangka panjang (Nader \& Todd, 1978).

\section{PENUTUP}

Model-model penyelesaian sengketa di atas sangat dipengaruhi oleh sistem nilai, keyakinan, norma, persepsi, dan sikap-sikap masyarakat dalam memaknai sengketa, dan dimensi-dimensi ini dalam perspektif antropologi hukum dikenal sebagai budaya hukum (legal culture) masyarakat dalam penyelesaian sengketa (Warasih, 1981). Pertanyaan yang muncul kemudian, bagaimanakah budaya hukum penyelesaian sengketa yang dianut masyarakat Indonesia? Dalam hubungan ini, Lev (1972) pernah melakukan penelitian mengenai budaya hukum penyelesaian sengketa dalam masyarakat Indonesia, khususnya masyarakat di daerah pedesaan Jawa dan Bali. Temuan penelitian tersebut pada pokoknya menyatakan seperti berikut:

* Dalam kehidupan sosial sebagian besar masyarakat Indonesia cenderung untuk menghindari terjadinya sengketa dengan siapa pun, karena nilai-nilai pergaulan sosial yang dianut Iebih bersifat personal, komunal, mengutamakan solidaritas, dan bernuansa magis. Karena itu, apabila terjadi sengketa maka cenderung diselesaikan melalui prosedur kompromi, konsiliasi, mengutamakan pendekatan personal dan kekerabatan .

Sengketa antar individu sedapat mungkin dihindari, dan kalau pun harus terjadi maka sengketa cenderung ditutupi dengan gaya hubungan sosial yang halus, untuk memperoleh penyelesaian yang tidak sampai merusak hubungan dan pergaulan sosial, apalagi menjatuhkan martabat atau merendahkan derajat pihak yang diajak bersengketa.

Fokus penyelesaian sengketa bukan pada penerapan peraturan hukum yang digunakan, tetapi Iebih pada upaya pelenyapan sengketa yang menjadi sumber ketegangan sosial. 
Makna penyelesaian sengketa pada persoalan kalah-menang (winlose solution), tetapi menjadi kewajiban bagi pihak-pihak untuk menghentikan sengketa dan meniadakan ketegangan sosial yang telah terjadi. Karena itu, yang diutamakan bukan penyelesaian substansi sengketanya, tetapi Iebih pada prosedur penyelesaian sengketanya.

- Pihak-pihak yang bersengketa Iebih melihat pihak ketiga (petugas hukum) yang dilibatkan untuk menyelesaikan sengketanya dan pada peraturan-peraturan hukum yang mengatur penyelesaian sengketanya. Karena itu, petugas hukum ditaati masyarakat bukan karena alasan yang berkaitan dengan masalah kepatuhan masyarakat terhadap hukum. 


\section{DAFTAR PUSTAKA}

- Gokma Toni Parlindungan S, Asas Nebis In Idem Dalam Putusan Hakim Dalam Perkara Poligami Di Pengadilan Negeri Pasaman Sebagai Ceriminan Ius Constitutum, Volume 2, Nomor 1, 2020.

- Gokma Toni Parlindungan S, Pengisian Jabatan Perangkat Nagari Pemekaran Di Pasaman Barat Dalam Rangka Pelaksanaan Otonomi Daerah, Ensiklopedia Of Journal, Vol 1 No 2 Edisi 2 Januari 2019.

- Harniwati, Peralihan Hak Ulayat Menurut Undang-Undang Nomor 18 Tahun 2004, Volume 1, Nomor 3, 2019.

- Jasmir, Pengembalian Status Hukum Tanah Ulayat Atas Hak Guna Usaha, Soumatera Law Review, Volume 1, Nomor 1, 2018.

- Jumrawarsi Jumrawarsi, Neviyarni Suhaili, Peran Seorang Guru Dalam Menciptakan Lingkungan Belajar Yang Kondusif, Ensikopedia Education Review, Vol 2, No 3 (2020): Volume 2 No.3 Desember 2020

- Mia Siratni, Proses Perkawinan Menurut Hukum Adatdi Kepulauan Mentawai Di Sebelum Dan Sesudah Berlakunya Undang-Undang Nomor 1 Tahun 1974 Tentang Perkawinan, Ensiklopedia Of Journal, Vol 1 No 2 Edisi 2 Januari 2019.

- Remincel, Dimensi Hukum Pelanggaran Kecelakaan Lalu Dan Angkutan Jalan Lintas Di Indonesia, Ensiklopedia Social Review, Volume 1, Nomor 2, 2019.

- R Amin, B Nurdin, Konflik Perwakafan Tanah Muhammadiyah di Nagari Singkarak Kabupaten Solok Indonesia 2015-2019, Soumatera Law Review, Volume 3, Nomor 1, 2020. 